\title{
ОСОБЕННОСТИ ВЕДУЩИХ ЦЕННОСТЕЙ И ИХ ВЗАИМОСВЯЗЬ С ИНТЕРНАЛЬНОСТЬЮ В ЮНОШЕСКОМ И ЗРЕЛОМ ВОЗРАСТАХ
}

\section{Афанасенко Инна Владимировна}

Статья посвящена изучению ведущих ценностей и их взаимосвязи с интернальностью у лиц юношеского и зрелого возрастов. Приводится обзор современных психологических исследований, посвященных данной проблеме. Эмпирическим объектом исследования выступили 80 человек, из них 40 человек в возрасте 19-24 лет - студенты разных специальностей 2. Ростова-на-Дону, и 40 человек в возрасте 40-45 лет - люди с высшим образованием, представители различных профессий г. Ростова-на-Дону. В данной статье рассмотрены преобладающие терминальные ченности, особенности структуры индивидуальной религиозности и показатели интернальности в группах респондентов юношеского и зрелого возрастов.

Характерной особенностью для респондентов юношеского возраста является доминирование ценности высокого материального достатка. Преобладающими жизненными сферами, в которых представители юношества в первую очередь стремятся реализовать свои ченности, являются сферы общественной жизни и увлечений, в то время как в группе зрелых людей жизненные сферы оказались не дифференцированы, что может объясняться индивидуальным своеобразием их распределения у людей этого возраста. Характерной особенностью мужчин зрелого возраста по сравнению с юношами-студентами является большая выраженность веры в Твориа, которая связана с внутренним локусом контроля.

Общий показатель интернальности у студентов связан с философским восприятием религии, развитием их религиозного самосознания, соблюдением религиозных обрядов и признанием религии как образиа моральных норм. Этот же показатель (интернальность) больще выражен у тех людей зрелого возраста, которые имеют хобби и стремятся к сохранению своей индивидуальности, и связан у них с верой в Творца, а также в явления, не объясненные наукой. Практическая значимость результатов исследования состоит в возможности их использования в психологическом консультировании клиентов по вопросам их ценностного и религиозного самоопределения. 
Ключевые слова: терминальные ценности, ченностные ориентации, жизненные сферы, индивидуальная религиозность, вера в Творца, интернальность, экстернальность, юношество, зрелость.

\section{Введение}

В отечественной психологии ценности и ценностные ориентации определяются через понятия отношения, отражения, установки и исследуются в понятийном аспекте их определения и соотношения [2], в динамическом аспекте их проявления [9], у учащейся молодежи [1, 2, 6, 13, 17], в связи с профессиональной ориентацией [11] и выбором [10, 14]. За рубежом представлены исследования ценностей в русле персонализма [19], в их связи с политическими убеждениями людей [20, 22], в кросс-национальном аспекте [21] и др. Ценностные ориентации формируют избирательное отношение человека к материальным и духовным ценностям, систему индивидуальных установок, убеждений, предпочтений, опосредованных личностными смыслами [3, 18].

Наиболее активно становление ценностной сферы личности происходит на этапе подростковой и юношеской социализации. Ценностно-смысловая сфера развивается у человека под влиянием социального окружения, но вместе с тем и сам человек активно формирует и конкретизирует ее содержание, принимая, изменяя или отвергая ценности и смыслы, предлагаемые обществом $[2,8,9,14]$.

В системе ценностей личности особое место занимает религиозность, которая рассматривается как одно из ключевых качеств личности и понимается в связи со смыслообразующими и мироописательными категориями $[4,13]$. Обращаясь к содержательному аспекту изучения религиозности, следует отметить разнообразие феноменов, включенных в ее состав. Представления о магии, религии и науке, их соотношение в рамках фундаментальных измерений отношения любого человека к миру рассматриваются в работах Б. Малиновского [12]. Религиозные ценности определяются «как ценности, обусловленные верой в сверхъестественное и возможностями непосредственного общения с ним, направленные на осуществление высшего смысла жизни человека, не сводимого к его биологическому существованию» [5, с. 138-139].

Классификационная модель ценностей, представляющая духовные, материальные и общечеловеческие ценности и взаимосвязь между ними, предложена в работе И. В. Федосовой. В качестве одной из причин социальных противоречий отмечается то особое значение, которое придается отношению личности к собственности как ценности [15]. Так, например, для студентов экономических специальностей наиболее важна ценность 
материального благосостояния [16]. Вместе с тем в научной литературе представлены результаты, отражающие высокую значимость для молодых россиян духовных ценностей [13], выраженных в том числе в стремлении получать моральное удовлетворение, удовольствие в большей степени от процесса деятельности, нежели от результата во всех сферах [1], а также высокую значимость творчества (для студентов гуманитарных специальностей) [16].

Ценности личности, сформированные в юношеском возрасте, определяют особенности и характер ее отношений с окружающей действительностью, тем самым в определенной мере детерминируя ее поведение и способствуя успешной социализации. Человек «социализированный» - значит «полностью интернализовавший нормы и ценности данной группы» [3, с. 31]. Источниками инкультурации ценностей для молодежи выступают семья, образовательные учреждения, референтные группы, а также информационная среда [8], географическое положение, идеология и религиозная вовлеченность [16]. Ведущими субъективными факторами, обусловливающими жизненные ценности учащейся молодежи, являются: жизненные цели, жизненный опыт (личные проблемы), личные качества студентов и вера $[11,13,14,16]$. В отличие от юношеского возраста зрелость является периодом своеобразной переоценки жизненных притязаний и личностных ценностей, изменения уже сформированной к этому возрасту структуры жизненных ценностей, личностные детерминанты которой до конца не изучены.

Указанные возрастные особенности личности определяют актуальность исследования специфики ценностной сферы, включая особенности ее религиозных представлений и выраженности интернальности у представителей юношеского и зрелого возрастов, различий в доминировании тех или иных видов ценностей и готовности принимать ответственность за разные события своей жизни. Особый исследовательский интерес вызывает изучение характера связи религиозных представлений личности с локусом ее контроля в различных жизненных сферах у представителей разных возрастов, и, в частности, у представителей поколения, родившегося в годы перестройки. Отсутствие научных работ, посвященных этим вопросам, обусловливает актуальность и новизну представляемого исследования.

Целью исследования стало выявление ведущих ценностей и их взаимосвязи с интернальностью у субъектов юношеского и зрелого возрастов.

\section{Объект и методы исследования}

Выборку составили 80 человек: 40 студентов (19-24 лет) разных специальностей г. Ростова-на-Дону и 40 человек (40-45 лет) с высшим 
образованием, представители различных профессий г. Ростова-на-Дону. По полу группы распределены равномерно, все опрашиваемые исповедуют православие.

Методы исследования: 1) психологическое тестирование - опросники: «Терминальные ценности» (ОТеЦ) И. Г. Сенина; «Структура индивидуальной религиозности» Ю. В. Щербатых; «Уровень субъективного контроля (УСК)» Е. Ф. Бажина, С. А. Голынкина, А. М. Эткинд; 2) методы математической статистики (программа STATISTICA 6.0): коэффициент ранговой корреляции R-Спирмена, критерий $\mathrm{X}^{2}$-Фридмана, критерий Т-Вилкоксона, U-критерий Манна-Уитни. Анализировались результаты с достоверностью $\mathrm{p} \leq 0,05$.

\section{Результаты исследования}

Для представителей юношеского возраста ведущими терминальными ценностями оказались ценности достижения и высокого материального положения, а для представителей зрелого возраста ценность достижений значимо доминировала над ценностью материального положения. Наиболее значимыми жизненными сферами для студентов оказались сферы общественных отношений и увлечений, а во взрослой выборке выявленные жизненные сферы оказались не дифференцированы.

Сравнительный анализ двух выборок мужского пола показал, что для юношей более значимыми, чем для мужчин зрелого возраста, являются сфера увлечений $(U=104)$ и стремление к сохранению собственной индивидуальности $(U=113)$. Среди женщин различий не выявлено.

В индивидуальной структуре религиозности респондентов выявлены следующие особенности. Студенты в религии склонны видеть преимущественно поддержку и утешение, склонны выполнять формальные требования православных традиций. В религиозной сфере они ищут ответы на вопросы о смысле жизни и Бытии, но не рассматривают ее как образец моральных норм. У мужчин зрелого возраста достоверно выше, чем у юношей, выражена вера в Творца $(U=476,5)$, что проявляется в их склонности видеть за происходящими событиями действие некой Высшей силы.

Интернальный локус контроля проявляется у студентов в области достижений и в области семейных отношений, а экстернальный локус контроля - в сфере производственных отношений и области неудач. У представителей зрелого возраста интернальность проявляется в сферах достижений, семейных и межличностных отношений, здоровья и болезни.

В зрелой группе сильнее, чем в юношеской, выражена интернальность в отношении здоровья и болезни $(U=481)$ и в области достижений $(U=590,5)$. 
В результате корреляционного анализа были выявлены взаимосвязи между показателями ценностной сферы и выраженностью интернальности в группах субъектов юношеского и зрелого возрастов. Склонность к выполнению религиозных обрядов сильнее выражена у студентов с высоким общим уровнем интернальности $(r=0,36)$. Также внутренний локус контроля связан у них с философским восприятием религии $(r=0,4)$, развитием их религиозного самосознания $(r=0,4)$ и признания религии как образца моральных норм $(r=0,46)$. Внутренний локус контроля в отношении физического самочувствия проявлен у тех представителей юношества, для которых значимы ценности креативности $(r=0,36)$ и активных социальных контактов ( $r=0,4)$, которые стремятся к самореализации в сферах увлечения и семейной жизни $(r=0,42)$. Интернальность в сфере межличностных отношений выше у тех студентов, которые отстаивают ценность собственного престижа $(r=0,32)$ и стремятся реализовывать себя в сфере обучения и образования $(r=0,41)$.

Специфика корреляционных взаимосвязей в группе мужчин и женщин зрелого возраста оказалась иной, чем в группе студентов. Общий показатель интернальности выше у тех, кто верит в существование Творца (Высшую силу) $(r=0,4)$, в не установленные наукой явления (телепатия, энергетический вампиризм и др.) ( $r=0,44)$, в магию $(r=0,5)$. Интернальность в сфере достижений связана со сферой увлечений $(r=0,32)$ и ценностью сохранения собственной индивидуальности ( $r=0,37)$. Верующие в Творца представители зрелой возрастной группы проявляют интернальность в сфере производственных $(r=0,4)$, межличностных отношений $(r=0,33)$ и в сфере здоровья $(r=0,33)$. А вот отсутствие у них ориентации на постулаты идеалистической философии и вера в магию в аспекте наведения порчи и колдовства связаны с их интернальностью в сфере неудач $(r=-0,32$ и $r=0,34)$.

\section{Заключение и выводы}

Полученные результаты позволяют сделать следующие выводы.

1. Выявленные в результате исследования достоверные различия в преобладании терминальных ценностей, особенности структуры индивидуальной религиозности и показателей интернальности касались доминирования ценности высокого материального достатка у студентов, что мы объясняем имеющейся у них фрустрированностью в материальной сфере вследствие отсутствия дохода от своей еще нереализуемой профессиональной деятельности. Представители юношества стремятся реализовать свои ценности преимущественно в сферах общественной жизни и увлечений, в то время как для зрелых людей жизненные сферы 
оказались не дифференцированы, что объясняется индивидуальным своеобразием их распределения в этом возрасте. Полученные результаты могут быть обусловлены разным характером социальной активности и профессиональной занятости у учащихся студентов и взрослых работающих людей. Для первых преимущественно характерны обучение, поиск профессиональных и личных возможностей самореализации, поиск и выбор партнера для близких отношений и создания семьи, что предполагает активное включение в социальное сообщество и широкий спектр социальных контактов. Для юношей-студентов вопросы самопознания и утверждение своей индивидуальности остаются более актуальными, нежели для мужчин зрелого возраста, у которых эти вопросы в той или иной степени оказываются решенными.

Зрелых мужчин от юношей-студентов отличает большая выраженность веры в Творца, связанной с внутренним локусом контроля, т. е. принимать ответственность за свою жизнь им помогает представление о мироустройстве как о согласованном и имеющем некий непостигаемый смысл Творении. Высокая интернальность в сфере здоровья и болезни и в области достижений обусловливается возрастными изменениями в функционировании организма и большим опытом собственных достижений в разных сферах жизни у представителей зрелой группы по сравнению со студентами.

2. Специфика характера связей ценностной сферы и интернальности у представителей юношества и зрелого возраста касается преобладания в них элементов структуры внутренней религиозности, причем качественно отличных у представителей разных возрастных групп. Общий показатель интернальности у студентов связан с философским восприятием религии, развитием их религиозного самосознания, соблюдением религиозных обрядов и признанием религии как образца моральных норм. В группе людей зрелого возраста выше интернальность у тех, кто имеет хобби и стремится к сохранению своей индивидуальности, и связана у них с верой в Творца, в не установленные наукой явления и магию. Можно предположить, что внутренний локус контроля у представителей молодого поколения обусловлен признанием ими духовно-нравственного авторитета религии конфессионального характера, а у взрослых людей - сохранением непрерывности процесса их внутреннего развития наряду с расширением диапазона восприятия явлений окружающей действительности.

Полученные результаты могут быть полезны в практике психологического консультирования по вопросам ценностного самоопределения и осознания системы религиозных воззрений в связи со способностью нести ответственность за происходящие жизненные события. 


\section{Литература}

1. Афанасенко И. В., Тащёва А. И., Габдулина Л. И. Ценностные ориентации в связи с социальной фрустрированностью обучающихся и работающих молодых мужчин и женщин // Гуманитарные и социальные науки. 2015. - № 4. - С. 172-183.

2. Бездухов В. П., Жирнова Т. В. Нравственно-ценностная сфера сознания студента: диагностика и формирование. - М.: Изд-во МПСИ, 2008. - 201 с.

3. Безумова Л. Г. Соотношение ценностей и потребностей в смысловой сфере личности студента // Вестник Самарской гуманитарной академии. Серия: Психология. - 2007. - № 2. - С. 29-36.

4. Богдановская И. М. Религиозный опыт личности как феномен психологического исследования // Диалог отечественных светской и церковной образовательных традиций: материалы Покровских педагогических чтений. - СПб.: Изд-во РГПУ им. А. И. Герцена, 2001. - С. 130-133.

5. Бокова О. А. К вопросу о теоретических основах изучения психологических феноменов ответственности и локуса контроля // Мир науки, культуры, образования. - 2014. - № 5. - С. 181-182.

6. Буравлева Н. А. Ценностные ориентации студентов // Вестник ТГПУ. 2011. - № 6 (108). - С. 124-129.

7. Думнова Э. М. Молодежь мегаполиса: социальное неравенство и ценности // Вестник ТГПУ. - 2012. - № 6 (121). - С. 54-58.

8. Ерохин Д. О. Характер взаимодействия аудитории с информационной средой и формирование ценностных ориентаций // Вестник университета (Государственный университет управления). - 2010. - № 7. - С. 43-46.

9. Журавлева Н. А. Динамика ценностных ориентаций личности в российском обществе. - М.: Изд-во ИП РАН, 2006. - 335 с.

10. Кузнецова Е. Г. Личностные ценности: понятие, подходы к классификации // Вестник ОГУ. - 2010. - № 10 (116). - С. 20-24.

11. Ладьина В. В. Ценностно-профессиональные ориентации студентов технических вузов: автореф. дисс. ... канд. психол. наук. - М., 2012.

12. Надточий И. О. Трансцендентное как сущность религиозного // Научные ведомости Белгород. гос. ун-та. Философия. Социология. Право. - 2010. Вып. 13. - Т. 14. - С. 264-269.

13. Павлык Н. В. Духовная личностная направленность как фактор гармонизации характера в юношеском возрасте // Национальный психологический журнал. - 2015. - № 1 (17). - С. 88-95.

14. Трещев А. М., Сергеева О. А. Психолого-педагогические условия формирования ценностных ориентаций гражданско-патриотической направленности у студентов-спортсменов // Вестник ТГПУ. - 2013. № 1 (129). - С. 25-31. 
15. Федосова И. В. Проблема ценностных ориентаций в научной литературе // Ценности и смыслы. - 2009. - № 2. - С. 75-92.

16. Черкасова А. А. Жизненные ценности студенческой молодежи в России и США: социологический анализ: автореф. дисс. ... канд. соц. наук. - Екатеринбург, 2012.

17. Щанкина Э. В. Субъектно-ценностный подход к формированию нравственных идеалов студентов колледжа // Известия Самарского научного центра РАН. - 2015. - Т. 17. - № 1 (3). - С. 615-619.

18. Яницкий М. С. Диагностика уровня развития ценностно-смысловой сферы личности: учебное пособие. - Новокузнецк: Изд-во МАОУ ДПО ИПК, 2010. - 102 с.

19. Perry R. B. The Realms of Value [Based on Gifford Lectures]. - Cambridge: Harvard University Press, 1954.

20. Schoemaker P., Tetlock P. E. Taboo scenarios: How to think about the unthinkable // California Management Review. - 2011 . - no. 54 (2). - pp. 5-24.

21. SchwartzS. H. Value orientations: Measurement, antecedents and consequences across nations // Measuring attitudes cross-nationally - lessons from the European Social Survey. Ed. by R. Jowell, C. Roberts, R. Fitzgerald \& G. Eva. - London: Sage Publ., 2006.

22. Tetlock P. E. Thinking about the unthinkable: Coping with secular encroachments on sacred values // Trends in Cognitive Science. - 2003. - no. 7. pp. 320-324. 